\title{
ANALISIS PENGENDALIAN INTERNAL KOPERASI SIMPAN PINJAM UBHARA JAYA
}

\author{
Maidani $^{1}$, Milda Handayani² ${ }^{2}$ Cahyadi Husadha ${ }^{3}$ \\ Program Studi Akuntansi, Fakultas Ekonomi dan Bisnis, Universitas Bhayangkara Jakarta Raya, Bekasi ${ }^{1}$ \\ Program Studi Manajemen, Fakultas Ekonomi dan Bisnis, Universitas Bhayangkara Jakarta Raya, Bekasi ${ }^{2,3}$ \\ $\underline{\text { maidani@dsn.ubharajaya.ac.id }}^{1}, \underline{\text { milda.handayani@ubharajaya.ac.id }}^{2}, \underline{\text { cahyadi.husadha@dsn.ubharajaya.ac.id }}^{3}$
}

Penulis untuk Korespondensi/E-mail: maidani@dsn.ubharajaya.ac.id

\begin{abstract}
Abstrak
Penelitian ini bertujuan untuk mengevaluasi pengendalian internal pada Koperasi Ubhara Jaya yang harus menjadi perhatian bagi Pimpinan dan pembina koperasi. Penelitian dilakukan dengan membandingkan sistem pengendalian internal yang dijalankan koperasi Ubhara Jaya dengan teori sistem pengendalian internal. Teknik pengumpulan data yang digunakan adalah wawancara, observasi, dan penelitian langsung ke objek. Berdasarkan hasil studi pengendalian internal koperasi Ubharajaya, dengan indikator pengendalian internal diantaranya; Struktur organisasi yang memisahkan tanggung jawab fungsional secara tepat, Sistem wewenang dan prosedur pencatatan yang memberikan perlindungan yang cukup terhadap kekayaan Koperasi, Praktik yang sehat dalam melaksanakan tugas dan fungsi-fungsi setiap unit organisasi, Karyawan yang mutunya sesuai dengan tanggung jawabnya. Dari hasil uji atas indicator tersebut, menunjukkan hasil bahwa pengendalian internal koperasi belum berjalan dengan baik, hal ini karena belum adanya struktur organisasi dan jobdesk yang jelas, mutu karyawan belum cukup baik. Selain itu prosedur permohonan pinjaman penyaluran kredit di koperasi tidak efektif karena tidak sesuai dengan prosedur yang ada dalam teori.
\end{abstract}

Kata Kunci : Internal Control, Cooperation.

\section{PENDAHULUAN (Left, $11 p t$, bold)}

Pengendalian Internal diperlukan bagi setiap organisasi baik sektor swasta maupun public, profit oriented maupun nirlaba serta perusahaan skala besar maupun skala kecil. Begitu juga Badan usaha Koperasi yang pendiriannya diharapkan dapat mensejahterakan anggota koperasi khususnya serta masyarakat pada umumnya. Sebagaimana yang diamanatkan dalam undang-undang koperasi nomor 25 tahun 1992 tentang perkoperasian. Menurut Undang-undang Koperasi No.25 Tahun 1992 Pasal 3 : "Koperasi bertujuan memajukan kesejahteraan anggota pada khususnya dan masyarakat pada umumnya serta ikut membangun tatanan perekonomian nasional dalam rangka mewujudkan masyarakat yang maju, adil, dan makmur berlandaskan Pancasila dan UndangUndang Dasar 1945".

Oleh karena itu, Atas dasar undang-undang perkoperasian tersebut, seharusnya setiap pengurus maupun anggota koperasi memiliki visi dan misi yang sama untuk memajukan dan mensejahterakan anggota dan masyarakat, termasuk dalam hal ini Koperasi Simpan Pinjam. Koperasi Simpan Pinjam dalam pendirian dan pelaksanaan operasionalnya diatur dalam peraturan Menteri KUKM Nomor 15 tahun 2015 tentang usaha simpan pinjam oleh koperasi. Akan tetapi, dalam pelaksanaan koperasi di Indonesia masih terdapat praktik-praktik menyalahi aturan dan ketentuan yang berlaku, sebagaimana yang terjadi Koperasi Simpan Pinjam Langit Biru di Banten pada tahun 2012. Pengurus Koperasi menggunakan dana koperasi untuk menjalankan usaha jual beli daging dan menginvestasikan dananya untuk usaha lain-lain yang pada akhirnya tidak dapat mengembalikan dana anggota koperasi. Kasus terbaru di tahun awal tahun 2020 ini adalah Kasus Investasi Bodong berkedok Koperasi Simpan Pinjam yang dijalankan oleh Pandawa Group.

Maraknya praktik-praktik yang menyalahi aturan dan ketentuan yang berlaku ini, tentunya diawali dari rendahnya pengendalian internal yang ada dalam sebuah badan usaha koperasi dalam hal ini Koperasi Simpan Pinjam. Oleh karenanya, 
penulis tertarik untuk melakukan penelitian tentang analisis pengendalian internal koperasi Simpan Pinjam Ubhara Jaya.

\section{TINJAUAN PUSTAKA}

\section{Pengendalian Internal}

Pada intinya pengendalian internal adalah suatu metode dan prosedur dalam rangka menjaga aset dan sumberdaya yang ada dalam organisasi agar tetap aman dan dikelola dengan baik untuk mencapai tujuan organisasi. Pengertian sistem pengendalian internal menurut Hery (2016, h. 132) sistem pengendalian internal terdiri atas kebijakan dan prosedur dibuat untuk memberikan kepastian bagi manajemen bahwa perusahaan telah mencapai tujuan dan sasarannya. Menurut Mulyadi (2010).

Unsur-unsur sistem pengendalian intern yang baik adalah:

1. Struktur organisasi yang memisahkan tanggung jawab fungsional secara tepat

2. Sistem wewenang dan prosedur pencatatan yang memberikan perlindungan yang cukup terhadap kekayaan perusahaan

3. Praktik yang sehat dalam melaksanakan tugas dan fungsi-fungsi setiap unit organisasi

4. Karyawan yang mutunya sesuai dengan tanggung jawabnya

\section{Tujuan Pengendalian Intern}

Manajemen mempunyai tiga tujuan tujuan umum dalam merancang sistem pengendalian intern yang efektif, yaitu realibilitas laporan keuangan, efisiensi dan efektifitas aktivitas operasi, dan ketaatan terhadap aturan hukum yang berlaku. (Arens, 2008)

Dalam menjalankan peranannya untuk melindungi kekayaan perusahaan dan menjamin kecermatan serta keandalan catatan keuangan sistem pengendalian intern pada perusahaan besar sekali pengaruhnya atas kelayakan laporan keuangan. Dengan demikian sistem pengendalian intern yang baik, akan berguna untuk:

1. Menjaga keamanan milik suatu perusahaan

2. Memeriksa ketelitian dan kebenaran data akuntansi

3. Memajukan efisiensi dalam operasi

4. Membantu menjaga agar tidak ada yang menyimpang dari kebijaksanaanmanajemen yang telah ditetapkan lebih dahulu

\section{Unsur-Unsur Sistem Pengendalian Intern}

Menurut Mulyadi (2010), Unsur-unsur

sistem pengendalian intern yang baik adalah:

1. Struktur organisasi yang memisahkan tanggung jawab fungsional secaratepat

2. Sistem wewenang dan prosedur pencatatan yang memberikan perlindungan yang cukup terhadap kekayaan perusahaan

3. Praktik yang sehat dalam melaksanakan tugas dan fungsi-fungsi setiap unit organisasi

4. Karyawan yang mutunya sesuai dengan tanggung jawabnya

\section{Koperasi}

Koperasi berasal dari kata co yang berarti bersama dan operation yang bermakna bekerja, sehingga koperasi dapat diartikan sebagai suatu wadah bagi kelompok orang yang bekerja secara bersama-sama.

\section{Penelitian Terdahulu}

Muntaz (2011) melakukan penelitian dengan judul Analisis Sistem Pengendalian InternPenerimaan Kas Pada Koperasi Aditya Kencana Baru (Kop-Akb) Pekanbaru Penelitian ini dilakukan pada Koperasi Aditya Kencana Baru tahun 2010 dengan menggunakan data primer dans ekunder yang diperoleh dari perusahaan.. Berdasarkan hasil penelitian yang dilakukan oleh penulis, dapat disimpulkan pembagian tugas atau pemberian wewenang dan tanggungjawab pada bagian keuangan belum ada, serta tidak adanya sistem pemerikasaan secara detail terhadap segala bukti, bukti-bukti catatan yang tidak memadai serta belum adanya pemeriksaan secara langsung maupun pemantauan mendadak (cashopname) oleh fungsi pemeriksa intern. Penulis memberikan saran pada Koperasi sebaiknya ada pemisahan tugas antar fungsi untuk menghindari kemungkinan penggunaan catatan akuntansi yang tidak benar yang dilakukan oleh karyawan, serta perlu dilakukan pemeriksaan mendadak pada setiap bagian, untuk meningkatkan kualitas kinerja karyawan.

Sedangkan hasil penelitian Agus, et al(2014) perlu pengoptimalan peran eksternal audit bagi kualitas laporan keuangan koperasi yang auditable dan secara tidak langsung akan meningkatkan kualitas dari laporan keuangan itu sendiri.

\section{METODE PENELITIAN}

Metodologi Penelitian adalah suatu cara yang sifatnya sistematis dan objektif dengan tujuan 
untuk mengumpulkan informasi atau data yang diteliti yang dapat digunakan sebagai pedoman untuk melaksanakan penelitian. Objek penelitian ini adalah Koperasi Simpan Pinjam Ubhara Jaya bidang jasa Simpan Pinjam bagi Anggota Koperasi. Penelitian ini bertujuan untuk membuat deskripsi secara sistematis, factual dan akurat mengenai prosedur pengendalian intern atas pengendalian internal Koperasi.

\section{Teknik Pengumpulan Data}

\section{Library Research}

Teknik penelitian yang dilakukan melalui buku-buku, majalah, diklat untuk memperoleh data-data sekunder yang berkaitan dengan penelitian tersebut.

Metode kepustakaan yang dipakai adalah; 1 .) Dengan membaca dan mempelajari buku-buku literatur yang berkaitan dengan penelitian yang dilakukan; 2.)Sumber internet

2. Field Research (Penelitian Lapangan)

Penelitian dilakukan dengan mengumpulkan data dan informasi langsung pada Koperasi Simpan Pinjam Ubhara Jaya sebagai objek penelitian diantaranya dengan Pengamatan (Observasi), yaitu dengan melakukan pengamatan langsung terhadap perusahaan untuk memperoleh data yang sebenarnya dan Wawancara (Interview), yaitu mengumpulkan data dengan mengajukan pertanyaan langsung kepada seorang informan dengan sistematik yang berlandaskan pada tujuan penelitian.

\section{Analisis Data}

Dalam penelitian ini penulis membandingkan antara pengendalian intern yang sesuai menurut teori dengan pengendalian intern yang ada di Koperasi Ubhara Jaya, berdasarkan unsur-unsur sistem pengendalian intern yang baik, yaitu :

1. Struktur organisasi yang memisahkan tanggung jawab fungsional

2. Sistem wewenang dan prosedur pencatatan

3. Pegawai yang cakap

4. Praktik-praktik yang sehat

\section{HASIL DAN PEMBAHASAN}

\section{Struktur Organisasi Yang Memisahkan Tanggung Jawab \\ Pada Koperasi Ubhara Jaya, struktur} organisasi yang digunakan masih sederhana, dan belum melaksanakan pemisahan tanggung jawab pelaksana koperasi secara baik, yakni peran pengarsipan dan pengadiministrasian keuangan koperasi masih dilaksanakan oleh pegawai yang menjabat secara struktural di Universitas. Oleh karena itu, kinerja pelaporan yang disampaikan masih belum memenuhi ketentuan sehingga pada saat dilakukan Audit Internal oleh Tim Dosen Fakutas Ekonomi, Pengurus Koperasi tidak dapat menunjukkan Akta Pendirian Koperasi yang dibuat oleh Notaris dan disahkan oleh Menteri, Anggaran Dasar dan Anggaran Rumah Tangga, Perangkat Organisasi (Rapat Anggota, Pengawas dan Pengurus).

Setiap organisasi baik privat, public, profit oriented maupun nirlaba, tentu memiliki Dasar pembentukan organisasi tersebut. Begitu pula yang menyangkut Koperasi. Sesuai dengan Undangundang nomor 17 tahun 2012 bab IV bagian kesatu dan kedua tentang Pendirian dan Anggaran Dasar, yang menjelaskan bahwa dalam pendirian Koperasi perlu ditetapkan dalam Akta Pendirian Koperasi yang dibuat oleh Notaris dan disahkan oleh Menteri. Selain itu, Koperasi juga harus memiliki Anggaran Dasar sesuai dengan pasal 16 UU/17 tahun 2012, bahwa Anggaran Dasar Koperasi sekurang-kurangnya memuat ; nama dan tempat kedudukan, wilayah keanggotaan, tujuan, kegiatan usaha, dan jenis Koperasi, jangka waktu berdirinya Koperasi, ketentuan mengenai modal Koperasi, tata cara pengangkatan, pemberhentian, dan penggantian Pengawas dan Pengurus, hak dan kewajiban Anggota, Pengawas, dan Pengurus, ketentuan mengenai syarat keanggotaan, ketentuan mengenai Rapat Anggota, ketentuan mengenai penggunaan Selisih Hasil Usaha, ketentuan mengenai perubahan Anggaran Dasar, ketentuan mengenai pembubaran, ketentuan mengenai sanksi, ketentuan mengenai tanggungan Anggota.

Perangkat pelaksana usaha Koperasi Ubhara Jaya merupakan Pegawai yang ada dalam struktur Universitas Bhayangkara Jakarta Raya, yang telah memiliki tanggung jawab untuk melaksanakan tugas regular mereka sehingga tidak dapat secara penuh mengemban tugas pelaksana koperasi. Koperasi Ubhara Jaya juga belum memiliki struktur organisasi yang melukiskan wewenang dan garis tanggung jawab langsung pimpinan terhadap bawahannya, sehingga setiap atasan mempunyai sejumlah bawahan yang masing-masing memberi pertanggung jawaban tugasnya kepada atasannya tersebut. Dalam pelaksanaannya, sering terjadi tumpeng tindih tugas dan fungsi masing-masing bagian khususnya mereka yang telah bekerja sebagai staf structural di Universitas Bhayangkara Jakarta Raya. Secara garis besar akan diuraikan unsur-unsur pengendalian intern yang ada pada sruktur organisasi Koperasi Ubhara Jaya 
diantaranya:

1. Belum Adanya bagian struktur organisasi yang didalamnya menggambarkan batasan - batasan wewenang dan tanggung jawab untuk masingmasing karyawan dan bagian yang terlibat dalam kegiatan operasional Koperasi Ubhara Jaya

2. Belum adanya uraian tugas (job description) secara tertulis untuk masing-masing bagian yang merupakan pedoman kerja yang jelas bagi para karyawan tentang tugas-tugas apa yang harus mereka kerjakan dan apa yang menjadi tanggung jawab mereka.

3. Belum adanya pemisahan fungsi antara bagianbagian yang menjalankan kegiatan operasi Koperasi, yaitu antara fungsi operasional Simpan Pinjam, pencatatan dan penyimpanan yang disertai batas-batas wewenang dan tanggung jawab yang jelas.

\section{Sistem Wewenang dan Prosedur Pencatatan}

Untuk wewenang dan prosedur pencatatan Koperasi Ubhara Jaya telah melaksanakan pencatatan cukup baik, yakni untuk pencatatan pembelian meliputi pembelian semua barang yang dibutuhkan oleh koperasi seperti kertas, pulpen, tinta dan lain-lain. Transaksi pembelian dicatat secara manual pada saat terjadinya transaksi, karena hal ini memudahkan pencatatan bagi pemilik sehingga tidak ada transaksi pembelian yang terlewat. Kemudian pencatatan Penerimaan iuran simpanan wajib dari gaji karyawan dilakukan pencatatan setiap bulannya, serta pencatatan pendapatan jasa dari pelunasan pinjaman dari anggota, yaitu pencatatan seluruh transaksi pendapatan jasa simpan pinjam diinput kedalam sistem yang disajikan oleh Bendahara dan dibuat laporan setiap harinya dengan cara manual yang diinput ke dalam aplikasi excel.

Sistem wewenang dan prosedur pencatatan di dalam suatu organisasi baik itu koperasi, merupakan alat bagi manajemen untuk menjalankan pengawasan terhadap kegiatan operasi perusahaan. Pengawasan tersebut dilakukan baik terhadap transaksi-transaksi yang terjadi maupun untuk mengklasifikasikan data akuntansi secara tepat dan benar.

Sistem wewenang dan prosedur pencatatan yang dilakukan oleh Koperasi Ubhara Jaya sudah berjalan dengan baik, hal ini dapat dilihat dari Laporan Keuangan yang mulai di buat pada tahun buku 2016. Karyawan juga sudah mengetahui apa yang harus mereka kerjakan dan kepada siapa mereka mempertanggung jawabkan pekerjaannya, akan tetapi masih terdapat tumpang tindih dalam pelaksanaan tugas dan fungsi antara fungsi pencatatan dan operasional.

\section{Koperasi Simpan Pinjam}

Dalam laporan keuangan koperasi tahun Anggaran 2015 dan 2016 terdapat pendapatan dari usaha parkir, sewa lahan kebun dan pendapatan unit usaha toko. Dan pada Laporan keuangan tahun anggaran 2017 terdapat pengeluaran untuk Biaya Aqua Galon, biaya pokok barang toko dan biaya lain-lain. Pengurus Koperasi belum menjalankan fungsi koperasi simpan pinjam sepenuhnya karena koperasi juga menjalankan usaha jual beli memahami maksud dan tujuan pendirian Koperasi Jasa, yaitu Koperasi yang melaksanakan kegiatan pelayanan jasa untuk seluruh anggota Koperasi

Berdasarkan fungsinya, Koperasi dibedakan menjadi 3 (tiga) jenis, yaitu Koperasi Konsumsi, Koperasi Produksi dan Koperasi Jasa. Sesuai dengan Akta Pendiriannya, koperasi Pegawai Ubhara ini adalah jenis koperasi Jasa (sesuai pasal 9), dan dalam pasal 15 ayat 1 (satu) bahwa kedudukan anggota sebagai pengguna jasa diwujudkan dengan partisipasi aktif untuk memanfaatkan kegiatan usaha melalui transaksi jasa simpanan dan transaksi jasa pinjaman oleh anggota koperasi

\section{Catatan akuntansi yang dilakukan}

Catatan akuntansi yang dilakukan oleh Koperasi Ubhara Jaya masih manual, bahkan menurut hasil Laporan Audit yang dilakukan masih terdapat transaksi yang di catat tidak dalam buku besar akan tetapi tidak sesuai dengan bukti yang tersedia. Sehingga tidak dapat diyakini bahwa transaksi yang dicatat benar terjadi atau tidak.

\section{Praktik-Praktik Yang Sehat}

Dalam suatu organisasi harus terdapat praktik yang sehat agar sistem pengendalian intern yang ada dapat berfungsi dengan baik. Koperasi Ubhara Jaya belum sepenuhnya melaksanakan Praktik yang sehat dalam operasional Koperasi Simpan Pinjam, hal ini terlihat dengan belum adanya pelaksanaan tugas yang sesuai dengan prosedur yang telah ditetapkan oleh pimpinan Universitas, Undang-undang Koperasi dan Peraturan Koperasi Simpan Pinjam.

Koperasi Ubhara Jaya belum menjalankan sepenuhnya Praktik-praktik sehat Organisasi terutama dalam hal pewujudan Tata Kelola Organisasi yang baik. Hal- hal tersebut diantaranya adalah; ditaati dan dilaksanakannya sistem dan prosedur pencatatan akuntansi baik pembelian maupun penerimaan. Akan tetapi, Terdapat 
kekurangan Bukti Pengeluaran untuk transaksitransaki yang terjadi pada tahun 2017 sebagaimana laporan audit yang disampaikan, dimana bukti yang kurang saji senilai Rp. 17.983.387,-

\section{Mutu Karyawan Yang Sesuai Dengan Tanggung Jawabnya}

Bagaimanapun baiknya struktur organisasi di dalam perusahaan dan praktik-praktik yang sehat yang dijalankan dengan sebaik mungkin, namun semuanya tergantung pada karyawan yang melaksanakan tugas yang di bebankan kepadanya. Tingkat kecakapan karyawan akan mempengaruhi berhasil tidaknya suatu sistem pengendalian intern dalam perusahaan. Untuk memperoleh karyawan yang tingkat kecakapannya cukup dan sesuai dengan yang dibutuhkan, bagian personalia dan umum telah mengadakan seleksi yang cukup baik.

Untuk menjamin transaksi kegiatan koperasi dijalankan dengan baik, karyawan yang melaksanakan tugas tersebut harus dapat dipercaya dan kompeten. Akan tetapi, karyawan sebagai pelaksana teknis koperasi dirangkap Pengurus Koperasi sebagai contoh ; Karyawan structural merangkap jabatan sebagai pengurus koperasi serta menjalankan fungsi pencatatan dan operasional koperasi.

Dilihat dari prosedur yang dilakukan oleh perusahaan dalam menentukan karyawan yang bertugas menjalankan teknis pengarsipan dan pencatatan akuntansi, maka dapat disimpulkan bahwa karyawan di dalam koperasi belum mempunyai kemampuan dan kecakapan yang cukup memadai dengan tuntutan tugas yang menjadi tanggung jawabnya. Sehingga dengan demikian dapat dikatakan bahwa pengendalian intern yang ada belum cukup baik.

\section{Pengawasan Tambahan}

\section{Laporan}

Laporan merupakan sarana bagi suatu bagian yang ada dalam perusahaan untuk mempertanggung jawabkan tugas-tugasnya, suatu laporan yang baik harus sesuai dengan informasi yang dibukukan dan tepat waktunya serta dalam laporan tersebut harus terdapat pengecualian, perbandingan dan komentar. Laporan harus dibuat secara ringkas. Pada Koperasi Ubhara Jaya dalam setiap kegiatannya selalu dibuatkan laporanlaporan, seperti adanya. Akan tetapi, laporan yang disampaikan belum sesuai dengan peraturan dan ketentuan yang berlaku.

Dari uraian di atas dapat disimpulkan bahwa sistem pengendalian intern yang ada di perusahaan belum cukup baik, karena laporan-laporan yang dibuat oleh perusahaan belum memenuhi prinsipprinsip dasar dari laporan keuangan Koperasi.

2. Staf Auditor Intern

Dalam sistem pengendalian intern yang baik, staf auditor intern merupakan bagian yang terpisah dan bebas dari bagian-bagian yang lain serta bertanggung jawab secara langsung kepada pimpinan perusahaan. Tugas dari staf auditor intern adalah melakukan pengawasan langsung terhadap jalannya operasi perusahaan dan melakukan pemeriksaan terhadap alat-alat pengendalian intern lainnya.

Dalam melakukan pengendalian intern terhadap kelancaran kegiatan operasionalnya, Koperasi Ubhara Jaya belum mempunyai staf auditor intern yang terpisah dan bebas dari bagianbagian lainnya.

\section{ANALISIS}

Dari Pembahasan tersebut di atas, maka penulis menemukan bahwa pengendalian intern terhadap pengelolaan kas yang selama ini dijalankan di Koperasi Ubhara Jaya, belum memenuhi aspek pengendalian intern yang efektif baik untuk tingkatan Koperasi, diantaranya sebagai berikut :

1. Struktur Organisasi Yang Memisahkan Tanggung Jawab:

a. Koperasi Ubhara Jaya belum memiliki struktur organisasi Koperasi yang jelas yang didalamnya menggambarkan batasan batasan wewenang dan tanggung jawab untuk masing-masing karyawan dan bagian yang terlibat dalam kegiatan operasional Koperasi Ubhara Jaya.

b. Belum adanya uraian tugas (job description) secara tertulis untuk masing-masing bagian yang merupakan pedoman kerja yang jelas bagi para pengurus Koperasi dan karyawan tentang tugas-tugas apa yang harus mereka kerjakan dan apa yang menjadi tanggung jawab mereka.

c. Belum adanya pemisahan fungsi antara bagian-bagian yang menjalankan kegiatan operasi Koperasi, yaitu antara fungsi operasional Simpan Pinjam, pencatatan dan penyimpanan yang disertai batas-batas wewenang dan tanggung jawab yang jelas. Pada saat dilakukan audit internal, koperasi tidak dapat menunjukkan Akta Notaris Pendirian Koperasi yang merupakan bagian terpenting dalam Koperasi karena hal tersebut merupakan fondasi utama bagaimana sebuah organisasi dapat berdiri dan menjalankan perannya. Hal ini terjadi 
karena, ketidak cakapan Karyawan yang menjalankan fungsi pengarsipan, sehingga Tata Kelola yang baik dalam Pengelolaan Koperasi belum tercapai sepenuhnya.

2. Sistem Wewenang dan Prosedur Pencatatan

a. Sistem wewenang dan prosedur pencatatan yang dilakukan oleh Koperasi Ubhara Jaya cukup baik, hal ini dapat dilihat dari Laporan Keuangan yang sudah mulai di buat pada tahun buku 2016. Karyawan juga sudah mengetahui apa yang harus mereka kerjakan dan kepada siapa mereka mempertanggung jawabkan pekerjaannya, akan tetapi masih terdapat tumpang tindih dalam pelaksanaan tugas dan fungsi antara fungsi pencatatan, pengarsipan dan .

b. Koperasi simpan pinjam menjalankan fungsi koperasi serba usaha, seharusnya menurut peraturan menteri koperasi tentang koperasi simpan pinjam Pendiriannya, koperasi Pegawai Ubhara ini adalah jenis koperasi Jasa (sesuai pasal 9), dan dalam pasal 15 ayat 1 (satu) bahwa kedudukan anggota sebagai pengguna jasa diwujudkan dengan partisipasi aktif untuk memanfaatkan kegiatan usaha melalui transaksi jasa simpanan dan transaksi jasa pinjaman oleh anggota koperasi.

c. Masih terdapat ketidaksesuaian antara nilai yang ada dalam Laporan dengan bukti yang tersedia. Hal ini tidak sesuai dengan prinsip Tata Kelola yang baik khususnya prinsip Accountability.

3. Praktik yang sehat dalam sebuah organisasi sulit terwujud apabila pengendalian intern organisasi tersebut tidak baik. Koperasi Ubhara Jaya belum menerapkan prinsip Tata Kelola Organisasi, yakni transparansi dan Akuntabilitas terutama dalam hal pencatatan akuntansi atas setiap transaksi yang terjadi.

4. karyawan yang menjadi pelaksana koperasi memiliki kompetensi yang baik hanya saja, karyawan yang menjalankan operasional koperasi masih rangkap jabatan dengan posisi structural di Universitas. Sehingga pekerjaan yang ada di Koperasi Ubhara khususnya mengenai pencatatan dan pengadiministrasian kurang baik dan tidak memenuhi unsure-unsur ketaatan terhadap peraturan dan ketentuan yang berlaku baik yang mengatur tentang Koperasi maupun pencatatan akuntansi yang berlaku umum.

\section{KESIMPULAN}

\section{Kesimpulan}

Berdasarkan pembahasan bab-bab sebelumnya tentang pengendalian intern terhadap pengelolaan Koperasi Ubhara Jaya, maka dapat disimpulkan bahwa Pengendalian intern belum dilaksanakan dengan baik, karena beberapa hal, yaitu sebagai berikut ;

1. Koperasi belum memiliki Struktur Organisasi serta jobdesk yang jelas beserta fungsi dan wewenangnya yang seharusnya dilaksanakan oleh setiap pengurus.

2. Karyawan di dalam koperasi belum mempunyai kemampuan dan kecakapan yang cukup memadai dengan tuntutan tugas yang menjadi tanggung jawabnya. Sehingga dengan demikian dapat dikatakan bahwa pengendalian intern yang ada belum cukup baik. Koperasi belum memiliki staf yang focus dalam menjalankan fungsi pencatatan dan pengarsipan

3. Pengelolaan penerimaan dan pengeluaran kas pada Koperasi Ubhara Jaya cukup baik, dimana setiap transaksi telah dibukukan menurut prosedur akuntansi yang berlaku, serta telah dimulainya pembuatan Laporan Keuangan untuk tahun buku 2016. Walaupun masih terdapat ketidak sesuaian antara pencatatan yang ada dalam Laporan Keuangan dengan bukti yang tersedia

4. Pengendalian intern atas pada Koperasi Ubhara Jaya kurang berjalan dengan efektif, hal ini karena sistem wewenang dan prosedur pencatatan kas belum dilakukan dengan baik, praktik yang sehat dalam pengelolaan kas, kecakapan karyawan dalam bekerja, tidak adanya pemeriksaan kas yang dilakukan secara periodic. Hal lain yang perlu diperbaiki adalah agar setiap fungsi menjalankan perannya masing-masing serta tidak dilakukan dengan tumpang tindih antara fungsi pencatatan dan fungsi operasional tidak menyatu atau harus terpisah agar pengendalian intern dapat lebih terlaksana dengan baik

\section{Saran}

Pengendalian intern untuk Koperasi Ubhara Jaya perlu diperbaik agar berjalan dengan baik, sehingga penulis mencoba memberikan beberapa saran yang mungkin dapat menjadi bahan pertimbangan pada bagi Koperasi di dalam pelaksanaan pengendalian intern organisasinya. Adapun saran penulis sampaikan pada Koperasi Ubhara Jaya adalah: 
1. Agar setiap satu bulan sekali dilakukan Audit Internal terhadap pengelolaan penerimaan dan pengeluaran kas

2. Selalu dilakukan training terhadap Staf Internal Audit, agar pengendalian internallebih efektif.

3. Agar setiap fungsi menjalankan perannya masing-masing serta tidak dilakukan dengan tumpang tindih antara fungsi pencatatan dan fungsi operasional tidak menyatu atau harus terpisah agar pengendalian intern dapat lebih terlaksana dengan baik

4. Koperasi Ubhara Jaya Perlu merekrut karyawan yang concern dalam menjalankan tugas dan fungsi operasional koperasi terutama dalam hal pencatatan dan pengarsipan.

\section{DAFTAR PUSTAKA}

Arens, Alvin A., Rndal J. Elder, Mark S. Beasley, 2008, Auditing dan Jasa Assurance, Edisi
Kedua belas, Jilid I, Jakarta : Erlangga.

Muntaz. 2011. Analisis Sistem Pengendalian Intern Penerimaan Kas Pada Koperasi Aditya Kencana Baru (Kop-Akb) Pekanbaru.Pekanbaru : Penerbit FE-UIN Sultan Syarief Kasi

Mulyadi. 2010, Sistem Akuntansi, BPFE, Yogyakarta

Munawir. 2003. Analisa Laporan Keuangan, Edisi Ke Empat, Liberty, Yogyakarta

Peraturan Menteri Koperasi Nomor 15 Tahun 2015 tentang Usaha Simpan Pinjam

Wahyudin Agus et.al 2014. Penguatan Sistem Pengendalian Intern (Spi) Sebagai Upaya Meminimalisir Praktek Tidak Sehat Dalam Tata Kelola Keuangan Koperasi, Rekayasa Vol. 12 No. 2, Desember 2014. Semarang Undang-undang nomor 25 tahun 1992 tentang Perkoperasian 